\title{
DEL CENTRO A LA PERIFERIA. LAS ESCUELAS DE CINE NACIONALES, LAS RUPTURAS DEL CORTOMETRAJE Y LAS NUEVAS FORMAS DE REPRESENTACIÓN DE LOS SECTORES POPULARES EN LA TRANSICIÓN DEL CINE CLÁSICO AL MODERNO
}

\author{
From the center to the periphery. The national film schools, the short films'ruptures and the new \\ forms of representation of the popular sectors in the transition from classical to modern cinema
}

Javier Cossalter*

\begin{abstract}
Resumen
El artículo aborda la problemática de las escuelas de cine de universidades nacionales y el cortometraje como agentes fundamentales en la transición del cine clásico al cine moderno, y en el posterior asentamiento de este último. A partir del desarrollo histórico de las cinco escuelas destacadas del período se podrán observar algunos rasgos compartidos que se erigieron como novedades: modalidades alternativas de concebir el cine, la descentralización de la producción y la apertura geográfica, la formación profesional y el compromiso socio-político colectivo. Luego, a través del análisis fílmico de dos corpus de cortos realizados al interior de dichas entidades se podrá constatar el carácter moderno de estas obras en dos vertientes primordiales: la experimentación estética y la autorreflexión del medio expresivo por un lado, y la adopción de un enfoque crítico con respecto a la representación de los sectores subalternos, por el otro; cualidades que, gracias a las potencialidades estructurales del film breve, rompen con la transparencia del relato y el punto de vista relativista o populista, características centrales del canon clásico dentro del cine argentino.
\end{abstract}

$<$ Escuelas de cine $><$ Cortometraje $><$ Modernidad $><$ Sectores populares $>$

\begin{abstract}
The article addresses the problems of film schools in national universities and short films as fundamental agents in the transition from classical cinema to modern cinema, and in the subsequent establishment of the latter. From the historical development of the five fundamental schools of the period, some shared features that were erected as novelties can be observed alternative ways of conceiving cinema, the decentralization of production and geographical opening, professional training and collective sociopolitical commitment. Then, through the filmic analysis of two groups of short films made within these entities, the modern character of these works can be seen in two primordial aspects: aesthetic experimentation and self-reflection of the expressive medium on the one hand, and the adoption of a critical approach in the representation of the subaltern sectors, on the other; qualities that, thanks to the structural potentialities of the short film, break with the transparency of the narration and the relativist or populist point of view, central characteristics of the classical canon within Argentine cinema.
\end{abstract}

$<$ Film schools $><$ Short film $><$ Modern cinema $><$ Popular sectors $>$

Recibido: 10/01/2018//Aceptado: 15/05/2018

* Doctor de la Universidad de Buenos Aires, área Historia y Teoría de las Artes, Becario Postdoctoral, Ayudante de primera de la cátedra Introducción al Lenguaje de las Artes Combinadas, Consejo Nacional de Investigaciones Científicas y Tecnológicas (CONICET) / Facultad de Filosofía y Letras de la Universidad de Buenos Aires (FFyL - UBA), javiercossalter@gmail.com 
Cossalter. Del centro a la periferia. Las escuelas de cine nacionales, las rupturas del cortometraje y las nuevas formas...

\section{Introducción ${ }^{1}$}

El cine clásico-industrial argentino tuvo su desarrollo, de acuerdo al consenso establecido por la historiografía, entre comienzos de los años treinta y finales de la década del cincuenta. Tomando como referencia el modelo hollywoodense, este se organizó alrededor de tres pilares que aseguraron una producción cuantiosa, relativamente estable y por sobre todas las cosas redituables: el sistema de estudios, estrellas y géneros. Este cine de carácter comercial y masivo, confeccionado casi exclusivamente en la provincia de Buenos Aires y en la Capital Federal, dominó durante aquella fase las modalidades productivas y estéticas de realización cinematográfica. No obstante, para fines de los años cuarenta, y más precisamente hacia mediados de la década del cincuenta, se expandieron otras formas de concebir el séptimo arte que manifestaban novedades en todas las facetas del quehacer fílmico: las escuelas de cine de universidades nacionales. Allí el cortometraje, en tanta práctica emergente, funcionaría como gestor principal de la renovación que alcanzaría su consolidación en la década del sesenta durante la modernidad cinematográfica.

En este sentido, el objetivo del presente trabajo consiste en estudiar la productividad de las escuelas de cine y del cortometraje consumado al interior de estas, como actores primigenios de impulso al cine moderno local y agentes fundamentales en el asentamiento del mismo. Para llevar a cabo esta propuesta planteamos tres hipótesis que vertebrarán las problemáticas que estructuran el artículo. La primera de ellas afirma que las escuelas de cine de universidades nacionales ${ }^{2}$ se erigieron en tantos espacios alternativos de producción fílmica, formación técnica y reflexión socio-teórica que promovieron la transición del cine clásico al moderno, junto con una expansión de la actividad cinematográfica a lo ancho del territorio. Las otras dos premisas del artículo están abocadas al cortometraje entendido como un medio de expresión audiovisual con cualidades funcionales potenciales que vehiculizaron los aspectos innovadores. Por un lado, el film breve evidenció rupturas estéticas con respecto al canon clásico a través de la experimentación del lenguaje fílmico y sus recursos. Por otro lado, el corto manifestó el compromiso social de los realizadores mediante la redefinición de la representación de los sectores populares a partir de una nueva perspectiva basada en la crítica y la denuncia de la condiciones de vida de dichos sectores subalternos. La pertinencia y relevancia de esta iniciativa radica en tres argumentos concretos. En principio, motiva esta investigación la ausencia de escritos que postulen al cortometraje alternativo como promotor del cine moderno local. En segundo lugar, el enfoque aquí esbozado permite deconstruir las periodizaciones tradicionales de la historia del cine argentino en torno a

\footnotetext{
1 Este artículo es el resultado de la investigación realizada en el marco de la estancia posdoctoral correspondiente al Programa de Posdoctorado de la Facultad de Filosofía y Letras de la Universidad de Buenos Aires.

2 Nos referimos al Instituto Cinefotográfico de la Universidad Nacional de Tucumán, la Escuela de Cine de la Universidad Nacional de La Plata, el Instituto de Cinematografía de la Universidad Nacional del Litoral, el Departamento de Cine de la escuela de Artes de la Universidad Nacional de Córdoba y el Instituto de Cine de la Universidad de Buenos Aires.
} 
la etapa clásica y la fase moderna, ${ }^{3}$ y de este modo subrayar la coexistencia de ambos paradigmas más allá de los bordes entre sus respectivos límites temporales. En tercera instancia, la apertura geográfica y los intercambios regionales en la producción fílmica nacional se presentan como sucesos novedosos que han sido poco estudiados.

De acuerdo a los postulados enunciados dividiremos el artículo en tres apartados. En el primero nos ocuparemos del desarrollo histórico de las cinco escuelas de cine poniendo el foco de atención en sus fases internas, y en la búsqueda de profesionalización, las formas de aprendizaje, la adaptación a las circunstancias socio-políticas y las relaciones interregionales como aspectos destacados. Se procurará entonces confirmar el estatuto de las escuelas en el camino de transición y afianzamiento del cine moderno. En la segunda sección analizaremos un corpus de cortos producidos en las escuelas con el interés de rastrear las marcas estéticas modernas. ${ }^{4}$ Allí se tendrán en cuenta los siguientes ejes: la hibridación de modelos cinematográficos, la explicitación de las huellas enunciativas y la autorreflexión del medio expresivo. Finalmente, en la tercera parte examinaremos una serie de films breves que abordan la representación de los sectores populares. ${ }^{5}$ En este segmento haremos hincapié en la centralidad del documental a la hora de poner en escena a los actores y sectores populares, trabajaremos sobre los diferentes objetivos políticos efectivizados por el cortometraje y tendremos en cuenta ciertas nociones teóricas claves para comprender la resignificación de las imágenes de dichos agentes sociales con respecto a los modos proferidos por el cine clásico. Nos basaremos principalmente en estudios sobre la cultura popular (Alabarces, 2002; Grignon y Passeron, 1991) y en el concepto de subalternidad (Gramsci, 1981). Cabe destacar que en los dos apartados de análisis fílmico nos concentraremos en obras tempranas que se inserten en la etapa de transición aunque también incluiremos ejemplos que excedan esa fase puntual para corroborar la consolidación de la concepción moderna a lo largo de las décadas siguientes.

\footnotetext{
${ }^{3}$ Existe cierta conformidad en la academia para establecer el inicio del cine clásico-industrial en el año 1933, con el estreno de la primera película con sonido óptico, ;Tango! (Luis Moglia Barth); y el cierre de la fase moderna con el golpe de Estado de 1976, momento en que se clausura una etapa a nivel político y también cultural (España, 2000; 2005). Ahora bien, los límites temporales relativos a la finalización del cine clásico y al comienzo del cine moderno no son tan certeros. Suele considerarse el año 1955/56 como bisagra puesto que el sistema de estudios entró en una crisis temporaria, cerrando prácticamente todas las casas productoras. No obstante, el cine de estudios seguiría activo luego de la parálisis, así como podemos observar el accionar de la escuela de Tucumán a partir del año 1946, en pleno apogeo de dicha modalidad estético-productiva. En este trabajo se discutirá entonces el marco temporal tradicional establecido.

${ }^{4}$ Los films escogidos son los siguientes: La verdadera historia de la primera fundación de Buenos Aires (Fernando Birri, 1959), Cirugía (Luis Vesco, 1960), Dimensión (Aldo Luis Persano, 1960), Lucho Robledo (Diego Eijo, 1965), Single -un ejercicio incompleto- (Alberto Yaccelini, 1967 [1970]).

${ }^{5}$ Las películas seleccionadas son: Tire dié (Fernando Birri, 1958[1960]), Fiesta en Sumamao (Aldo Luis Persano, 1961), Los 40 cuartos (Juan Fernando Oliva, 1962), Casabindo (Jorge Prelorán, 1965), Ceramiqueros de Traslasierra (Raymundo Gleyzer, 1965), Monopolios (Miguel Ángel Monte, 1975).
} 


\section{Hacia otras formas de producción y realización. Las escuelas en la transición y consolidación del cine moderno}

Desde la apertura a la industrialización de la cinematografía local a comienzos de los años treinta con la creación de los primeros estudios -Lumitón (1931) y Argentina Sono Film (1933) - y la sonorización sin discos, la mayor parte del cine filmado en nuestro país emergía dentro de los límites de la actividad de las productoras cinematográficas, ubicadas casi exclusivamente en la Capital Federal y sus alrededores. ${ }^{6}$ Los resquicios ocupados por un cine amateur o de tipo independiente eran escasos. ${ }^{7} \mathrm{De}$ este modo, dos rasgos estructurales caracterizaron a la producción del cine clásico: la concentración geográfica y el carácter industrial-comercial. La expresión cine argentino en este período respondía metonímicamente a los films concebidos desde Buenos Aires para el gran público.

Como ya anticipamos, las escuelas de cine hasta entonces inexistentes ${ }^{8}$ plantearon una diversificación tanto de las zonas como de los modos de producción, impulsando el despliegue de nuevas formas expresivas, la ampliación del campo de sentido y enfoques socio-políticos novedosos. No obstante, aunque estas modalidades y sus implicancias estético-políticas se instalaron fuertemente a partir de mediados de los años cincuenta, los inicios de la transición entre los paradigmas clásico y moderno pueden remontarse, paradójicamente, a un momento de auge del cine clásico-industrial: la creación en 1946 del Instituto Cinefotográfico de la Universidad Nacional de Tucumán. Ahora bien, no todos los centros de formación asumieron las mismas funciones en cuanto a la experimentación, la pretensión de profesionalización y la politización. Por tal motivo, distinguimos en esta sección dos grupos de polos de aprendizaje. El primero está comprendido principalmente por el ya mencionado Instituto de Tucumán, cuyo interés fundamental reside en su prematura e inaugural fecha de nacimiento. También podemos señalar aquí al Instituto de Cine de la Universidad de Buenos Aires. En ambos, el compromiso político radical estuvo ausente, la experimentación se practicó de forma aislada y la producción estuvo más bien ligada hacia fines educativos, científicos y pedagógicos. El segundo está constituido por la Escuela de Cine de la Universidad Nacional de La Plata, el Instituto de Cinematografía de la Universidad Nacional del Litoral y el Departamento de Cine de la escuela de Artes de la Universidad Nacional de Córdoba. Estas entidades, en cambio, se distinguieron por sostener de forma activa la experimentación estética, la formación profesional y el accionar político. A pesar de estas divergencias dos factores en común engloban a todos estos centros formativos: la puesta en marcha de una red de relaciones audiovisuales interregionales y la presencia

${ }^{6}$ Film Andes S.A., fundada en la provincia de Mendoza en 1944, se convirtió en una excepción a dicho estado de situación.

${ }^{7}$ Durante los comienzos del período clásico podemos destacar al menos dos espacios de producción y exhibición que se desarrollaron por fuera de los canales industriales: el Cine Club Buenos Aires, creado en 1928, y el Cine Club Argentino fundado en 1932. Ya para 1949 se constituyó el Ateneo Meliés, dedicado a un cine-arte realizado en $16 \mathrm{~mm}$.

${ }^{8} \mathrm{Al}$ no existir un espacio institucional dedicado a la formación, hasta el momento el conocimiento se adquiría en la práctica misma al interior del set de filmación. Generalmente se comenzaba colaborando en rubros de asistencia. 
activa del cortometraje en tanto medio de expresión y transición hacia los nuevos valores artísticos y extra-estéticos.

\section{II.1. Tucumán y Buenos Aires}

Una de las particularidades del Instituto Cinefotográfico de la Universidad Nacional de Tucumán, como bien hemos señalado, es la fecha de su fundación. La entidad tucumana fue creada en el año $1946^{9}$ y estuvo dirigida desde sus orígenes por Héctor Peirano. Al año siguiente se fijó un reglamento interno para el Instituto y sus dependencias. En la resolución se establecía que: "El Departamento Cinematográfico tiene como función específica, la producción de películas documentales, sociales, científicas, didácticas, dramáticas y de divulgación popular" (Mastracchio, 2006: 10). En las Memorias del Instituto de 1948 se expresaba que rápidamente adquirieron tres cámaras portátiles y un equipo de óptica, aunque el revelado, el montaje y la sonorización debían efectuarse en Buenos Aires. Es decir que aunque los polos productivos habían comenzado a extenderse, las herramientas y maquinarias indispensables para concretar y completar los films estaban todavía centralizados. En este contexto, el cortometraje fue un medio esencial desde los comienzos: ese año se terminaron diez películas de uno y dos rollos. Estas fueron etiquetadas como cine-documentos. ${ }^{10} \mathrm{Y}$ de acuerdo a los temas que se desprenden de los títulos de estos films se evidencia un interés por retratar la cultura local-provincial.

Al año siguiente se iniciaron las actividades docentes con cursos de Fotografía y Cinematografía. El plan de estudios establecía que en el tercer año los alumnos aprenderían historia del cine así como se involucrarían en la práctica fílmica, trabajando en torno al material sensible, la iluminación y otras cuestiones técnicas. En 1950 la escasez de celuloide trabó en parte la actividad. Las partidas conseguidas fueron utilizadas para completar proyectos en curso que respondían al carácter de cine-documento. En 1954 un incendio devastó al Instituto y prácticamente la totalidad de los films resultaron perdidos. Cuatro años más tarde empezó a funcionar en otra dependencia y en 1960 se consolidó en una sede definitiva. Fue en 1958 cuando se filmó el primer cortometraje argumental, El caminante, donde actuaron figuras del teatro vocacional.

A comienzos de los sesenta se creaba dentro de esta Universidad el Centro de Comunicaciones Audiovisuales, organismo que reforzaba la idea de trabajar de forma experimental y veía la necesidad urgente de formar gente, como si el Instituto no estuviera logrando ese cometido. Asimismo, se reflexionaba sobre la posibilidad de crear un cineclub para que los alumnos pudieran tener acceso a las obras de la cinematografía mundial. En 1962 este Centro se incorporó al Instituto Cinefotográfico.

\footnotetext{
${ }^{9}$ Si bien el Instituto no legó un grupo de egresados-realizadores reconocibles, y la experimentación estuvo reducida a unos pocos intentos, debe destacarse el año de iniciación de las actividades puesto que la historiografía del cine omite la presencia de las escuelas hasta mediados de los años cincuenta.

${ }^{10}$ Algunos ejemplos fueron: Tucumán recibe la Visita de los Becarios Americanos, Una Brillante Trayectoria, Acción de Gobierno, Conquistando Derechos, Deportes y Notas para el recuerdo, Construcción del Dique Escaba, La Fiesta de la Juventud, Rumbos de Cultura y Seda Natural.
} 
Cossalter. Del centro a la periferia. Las escuelas de cine nacionales, las rupturas del cortometraje y las nuevas formas...

Ahora bien, entre 1962 y 1967 se produjeron tres actividades destacadas: en primer lugar, el ICUNT colaboró con instituciones culturales mediante préstamos de cortos realizados por el Instituto -En Tierra del Silencio, Tiempo de Adoración y El Caminanteque fueron exhibidos en el Tercer Festival Nacional de Folklore de Cosquín (1963), en el Primer Festival del Folklore Sureño de Mar del Plata y en la rama Folklore del Fondo Nacional de las Artes. En segundo lugar, se dictó un curso sobre "Aplicación de los medios audiovisuales para la Educación", uno de los objetivos primordiales de la entidad. Por último, cabe resaltar el convenio establecido con el Fondo Nacional de las Artes para llevar a cabo el Relevamiento Cinematográfico de Expresiones Folklóricas Argentinas, programa que se desarrolló bajo la dirección del cineasta Jorge Prelorán y la coordinación del Dr. Augusto Raúl Cortázar, entre julio de 1963 y diciembre de 1967. Dicha experiencia le permitió al realizador "viajar por las regiones del centro y noroeste, para documentar una serie de eventos de tenor folklórico y rescatar así cosas auténticamente argentinas para mostrar a los demás argentinos" (Rossi, 1987: 22). En total se registraron diecinueve películas como parte de esta travesía -la mayoría cortometrajes y algún mediometraje- y fueron estrenadas conjuntamente en un ciclo acaecido en el Teatro San Martín en noviembre de 1969. De este modo se manifiesta entonces una voluntad por estrechar los lazos interregionales a través de la difusión de obras fuera de las fronteras de realización y acuerdos de producción itinerante con el objetivo de divulgar las distintas culturas locales.

Finalmente, hacia 1966 el Instituto trabajó en la puesta en marcha de la Televisión Universitaria y prácticamente todos los recursos de la Universidad se volcaron hacia aquella tarea, dejando de lado al ICUNT. Luego de la muerte de Peirano en 1969 y la posterior asunción de Néstor Gómez, las sucesivas instancias de gobierno colocaron a funcionarios que desconocían la utilidad y riqueza del audiovisual, y desatendieron por completo al ICUNT. Entre 1973 y 1984 sufrió sucesivos cambios de dependencia. En la actualidad el Instituto continúa en funcionamiento.

El Instituto de Cine de la Universidad de Buenos Aires, que dependía del Departamento de Cultura de la Universidad, fue creado en 1955 y estuvo a cargo de Aldo Luis Persano. Sin convertirse en una entidad fuerte, puesto que no había concretado un plan de estudios definido, el denominado ICUBA estaría abocado a la formación teórica y a la gestión de cursos de técnica cinematográfica con una dinámica de taller. Este no organizó los estudios de forma sistemática sobre un alumnado estable. La formación se ofrecía de modo complementario y no había una intención profesional como en las escuelas que examinaremos a continuación. Sin embargo, aquí también arribarían realizadores invitados en calidad de docentes. Este es el caso de Víctor Iturralde Rúa que impartió en 1958 un curso sobre historia del cinematógrafo. Por otro lado, el polo productivo se hizo presente, especialmente a través del cortometraje.

En relación a los films realizados por el Instituto, Nadia Paola Robles y Sofía Bilbao expresan que: "Este cine tomará la forma de cortometrajes, por razones de tipo presupuestarias y por ser la herramienta más adecuada para el film documental, pedagógico e informativo" (Robles y Bilbao, 2011: 12). Si bien es cierto que dicho cine 
estaba orientado mayormente hacia fines pedagógicos y científicos -como los ejemplos de Erosión del suelo, Actividades cardíacas de un perro y Crónica en Maciel-, cortos como Dimensión (1960) y Fiesta en Sumamao (1961) de Aldo Luis Persano, dedicados a la experimentación y al folklore, desbordaban tales objetivos. En este sentido es posible enmarcarlos dentro de los rasgos generales del cine moderno, por lo que serán examinados en los respectivos apartados reservados al análisis fílmico. Finalmente, como relatan las investigadoras mencionadas, los últimos registros de cortos del Instituto datan de finales de 1963 y la experiencia del mismo concluye concretamente con los inicios del golpe de Estado en 1966. Si bien dicha institución no adquirió un sesgo político explícito, la Universidad en general fue particularmente atacada por el gobierno de facto.

En definitiva, además de diferenciarse por la no politización de los centros, estas dos escuelas se constituyeron en tanto espacios alternativos de producción fílmica -con respecto a la industria del cine- y tomaron al corto como una instancia de formación y un medio de expresión cultural, científico y educacional. Algunas de sus producciones breves se erigieron entonces como exponentes de la transición y el asentamiento del cine moderno, tanto en el nivel productivo como en términos temáticos y estéticos.

\section{2. La Plata, El Litoral, Córdoba}

Estas tres escuelas cumplieron una función específica en materia de formación de realizadores y técnicos, y brindaron a los aprendices un impulso tendiente a retratar una nueva realidad social. El desarrollo de un camino similar compartido por ellas nos permite organizar este recorrido teniendo en cuenta tres grandes etapas entre mediados de los años cincuenta y mediados de los setenta: la primera de gestación, la segunda de consolidación y la tercera de politización, proseguida del cierre de las instituciones hacia el golpe de Estado de 1976.

\section{Primera fase: surgimiento y gestación}

En 1955 se llevó a cabo un curso de aproximación a la cinematografía en la Escuela Superior de Bellas Artes de la Universidad Nacional de La Plata a cargo de Cándido Moneo Sanz. Debido al éxito de la convocatoria y la ausencia de un campo de educación formal en el ámbito cinematográfico se consideró institucionalizar el área. En junio de 1956 se creó el Departamento de Cinematografía comandado por Moneo Sanz. La falta de especialistas en el rubro de enseñanza técnica y teórica desembocó en la convocatoria de gente formada en el medio, generalmente de Buenos Aires, como Rolando Fustiñana, Edmundo Eichelbaum, Eduardo Blanco Amor, Narciso Pousa, Arsenio Luis Martínez y Pablo Tavernero, entre otros. Una vez más se explicita la intención de abrir nuevos polos de realización por fuera de la Capital Federal, aunque el capital intelectual para alcanzar el cometido estuviera concentrado en la metrópolis central. El objetivo inicial estaba puesto en la formación de realizadores y se otorgaría el título de Realizador cinematográfico. Sin embargo, el documental, sobre el cual se focalizó la atención en los primeros años, sería considerado como una herramienta de expresión y 
Cossalter. Del centro a la periferia. Las escuelas de cine nacionales, las rupturas del cortometraje y las nuevas formas...

acción al margen de un cine de tipo comercial. Durante este período, "la formación tenía una fuerte orientación teórica, con un perfil de producción cercano a las actividades cineclubísticas no comerciales" (Massari, Peña y Vallina, 2006: 41). Asimismo, Moneo Sanz hacía especial hincapié en el aprendizaje de la técnica y el guión. A su vez, gracias a la presencia del historiador y crítico Fustiñana -y la Cinemateca Argentina- se pudo mantener un vínculo estrecho con el cortometraje producido principalmente en Europa y conocer las novedades en el terreno del documental y del cine experimental. Como ejemplo de imbricación entre estos dos tipos de cine en la producción de la escuela citamos al cortometraje -film-tesis- Cirugía (Luis Vesco, 1960), que será abordado en el apartado siguiente. Hacia 1961/62 se produjeron ciertas modificaciones que nos llevarían a la próxima etapa.

Por otro lado, Fernando Birri llegó a la provincia de Santa Fe en 1956 luego de haber estudiado cine en el Centro Sperimentale di Cinematografia di Cinecittá, en Italia. ${ }^{11}$ En septiembre de ese año el rector de la Universidad Nacional del Litoral -Dr. Josué Gollán- lo invitó a dictar un seminario corto. Influido por el neorrealismo comenzó con la producción de fotodocumentales a través de los cuales se intentaba retratar aspectos de la realidad local de forma crítica. Gracias al éxito de dicha experiencia se creó en abril de 1957 el Instituto de Cinematografía de la Universidad Nacional del Litoral con el propósito de formar cineastas. A partir de la idea de realizar un cine realista, nacional, popular y crítico nació la primera encuesta social filmada tomando como base uno de los fotodocumentales previamente concebidos: Tire dié (1958 [1960]). Este cortometraje registra la vida de los integrantes de una villa miseria al borde del ferrocarril y el acto mismo de los niños que se acercan a pedir monedas en el instante del paso del tren. Gracias a las nuevas posibilidades técnicas - cámaras livianas y una película de mayor sensibilidad- este film inauguró una corriente que ponía en imagen, de una manera auténtica y realista, a aquellos sectores anteriormente marginados. Los primeros años fueron fructíferos en cuanto a sus producciones: entre otros cortos mencionamos a López Claro, su pintura mural americana (Juan Oliva, 1960), Feria Franca (Hercilia Marino, 1961), Los 40 cuartos (Oliva, 1962) y La pampa gringa (Fernando Birri, 1963). Aquí, como en el Instituto de Tucumán, también predominó el interés por abordar tópicos y personajes locales, y estos ejemplos focalizaron de forma explícita sobre la representación de los sectores populares. De este modo la entidad se convertía en un núcleo de reflexión e innovación que se posicionaba, al igual que su compatriota platense, en la vereda de enfrente respecto al cine masivo que aún se realizaba en Buenos Aires. No obstante, para 1962 dos hechos marcaron el alejamiento de Birri y el final de esta primera etapa: la prohibición de Los 40 cuartos y la intervención económica al Instituto por una supuesta malversación de fondos.

En 1959 la Dirección de Cultura de la Provincia de Córdoba impulsó la creación de un centro de enseñanza, de carácter terciario, con el nombre de Instituto de Cine Arte. ${ }^{12}$ Este estuvo activo hasta 1963, momento en que fue cerrado por el cambio de

${ }^{11}$ Cabe destacar que en Europa las escuelas cinematográficas significaron un impulso concreto para la gestación de los Nuevos Cines. Ver: Monterde, Riambau y Torreiro (1987).

12 Esta información se desprende de una entrevista realizada por Fernando Ramírez Llorens a Oscar 
autoridades. Durante estos años se logró aunar a un grupo de alumnos que luego del cierre llevaría a cabo grandes iniciativas como las de crear el Cineclub Sombras y realizar algunos cortometrajes. Dicho grupo de personas constituyó la base inicial de gestación del Departamento de Cinematografía de la escuela de Artes de la Universidad Nacional de Córdoba. "En agosto de 1964 se obtuvo la aprobación del HCS [Honorable Consejo Superior] para 'iniciar actividades tendientes a la puesta en marcha del Departamento de cine', a través de un equipo de técnicos idóneos constituido por concurso oficial, que se denominó: "Grupo Piloto de Cine"" (Moreschi, 2012: 213). El dictamen estuvo en manos de un jurado especializado invitado de Buenos Aires y el equipo se conformaba por técnicos y realizadores independientes -entre ellos, Eduardo Bocio, Miguel Ángel Biasutto, Simón Banhos, Walter Mignolo y Oscar Moreschi, quienes ese mismo año realizaron el cortometraje experimental Más de la mitad-. Por otra parte, el Departamento se construyó a partir de tres unidades: la Escuela de Cine con dos carreras, un Centro de Producción y un Centro de Extensión o Difusión. De esta forma, se realizaron cursos de iniciación al cine y se puso en marcha el Cineclub Universitario, así como se produjeron ocho cortometrajes documentales en $16 \mathrm{~mm}$. con temáticas locales ${ }^{13}$ y se elaboró, para 1966, un primer plan de estudios. En los inicios se tomó el ejemplo de la Universidad Nacional del Litoral en cuanto a su impronta documental y social, la producción de bajos costos y la primacía del cortometraje. También se incorporó el cine experimental gracias al contacto con el National Film Board de Canadá. ${ }^{14}$ Al mismo tiempo, el arquitecto y director del Departamento Raúl Bulgheroni estableció convenios con el Fondo Nacional de las Artes y con la Universidad Nacional de La Plata para producir películas documentales con directores reconocidos: Pictografias del Cerro Colorado (Raymundo Gleyzer y Humberto Ríos, 1965), Ceramiqueros de Traslasierra (Gleyzer, 1965) y posteriormente Manos pintadas (Jorge Prelorán, 1971), entre otras. Al igual que los films realizados por Prelorán bajo el acuerdo entre el Fondo Nacional de las Artes y el Instituto de Tucumán, los cortos recién mencionados también evidencian la intención de poner en escena las identidades de comunidades regionales. Finalmente, el comienzo del dictado de clases en 1967 selló la inauguración del segundo momento.

\section{Segunda fase: consolidación}

El rasgo principal de esta etapa en las tres escuelas es el fortalecimiento de la tarea de formación profesional, ya sea mediante la concreción del dictado de clases y la certificación del título ofrecido, la inclusión de nuevos docentes, la diversificación de la oferta o el crecimiento del alumnado. Dentro del Departamento de Cine de la Universidad Nacional de La Plata este afianzamiento estaría marcado por la legitimación del plan de estudios en 1961 con el otorgamiento del título universitario de Licenciado

Moreschi, pilar fundamental del posterior Departamento de Cinematografía: Ramírez Llorens (2013).

${ }^{13}$ Algunos títulos fueron: El hacer artístico en la UNC, Difunta Correa, Laguna Blanca y Dique Río Dulce.

14 Para estos momentos ya estaba funcionando el Departamento de animación fundado por Norman McLaren, el cual producía cortos de animación experimental. Fue Víctor Iturralde Rúa quien llevó a la escuela de Córdoba estas experiencias. Asimismo, McLaren estuvo presente en el Primer Festival de Cine Documental y Experimental de Córdoba organizado por la Universidad Católica en 1966. 
Cossalter. Del centro a la periferia. Las escuelas de cine nacionales, las rupturas del cortometraje y las nuevas formas...

en Realización Cinematográfica, y por la entrada de un grupo nuevo de alumnos que le aportaría a la entidad sangre nueva -entre ellos, Armando Blanco, Carlos Fragueiro y Oscar Garaicochea-. En aquellos años, y al igual que en la Universidad de Córdoba, se consolidó un área de divulgación la cual venía desarrollándose desde tiempo atrás. ${ }^{15}$ En 1962 renunció Moneo Sanz y luego de un interinato de Fustiñana tomó la jefatura Ernestina Guzmán. La carrera adoptó en este tramo un perfil profesional y por tal motivo se incorporaron en calidad de docentes realizadores y técnicos provenientes del Nuevo Cine argentino -Rodolfo Kuhn, José Martínez Suárez, Simón Feldman, Antonio Ripoll, David José Kohon y René Mugica, entre otros- cuyas experiencias innovadoras serían transmitidas y volcadas por los alumnos en sus cortos: ejemplos como Hombres de río (Diego Eijo, 1965), fotodocumental sobre un grupo de pescadores; Lucho Robledo, del mismo año y director, en torno a un obrero que sueña ser cantor; Single -un ejercicio incompleto- (Alberto Yaccelini, 1967 [1970]), film fallido y experimental acerca de un remero. A este grupo de prestigiosos se les sumó Humberto Ríos, quien fuera invitado a dictar clases entre 1961 y 1965, y Fuad Quintar, el cual fuera nombrado profesor de realización y montaje, ambos recientemente egresados del IDHEC de París. Hacia 1968 problemas internos derivaron en la renuncia de Guzmán así como también en la de muchos de los docentes. La posterior reestructuración de la escuela daría paso a la tercera fase.

Por su parte, en 1963 asumió Adelqui Camusso como director del Instituto en la Universidad del Litoral abordando un camino diferente al de Birri, si bien habían estudiado juntos en Roma. En este sentido, se abrieron tendencias más esteticistas, manteniendo la preocupación social. Este es el caso de Jorge Goldenberg con su film Reportaje a un vagón (1963), y el de Gerardo Vallejo, que tuvo su paso por la escuela con dos cortometrajes: Azúcar (1963) y Las cosas ciertas (1965). Para aquel entonces había crecido el número de alumnos y la cantidad de equipos técnicos. Sin embargo, el Instituto no era bien visto por el gobierno de Onganía, como todas las dependencias universitarias. Por tal motivo, "algunos estudiantes optaron por abandonar los estudios. Otros recurrieron a la ayuda económica del Fondo Nacional de las Artes, o del Instituto Nacional de Cinematografía, para poder diplomarse" (Ceccato y Maina, 1990: 9). Por ejemplo, Dolly Pussi pudo concretar su film-tesis, Pescadores (1968), corto netamente político de denuncia acerca de las condiciones de trabajo de los pescadores en las zonas costeras de la provincia de Santa Fe. Un año más tarde, y debido a una nueva intervención a la Universidad, renunció Camusso, hecho que desembocaría en el final de este período.

Finalmente, la consolidación en la Universidad Nacional de Córdoba se produjo con los primeros profesores que llegaron desde Buenos Aires para el inicio de clases en 1967, y que fueron Víctor Iturralde Rúa y José Martínez Suárez, a quienes les siguieron Simón Feldman y Adelqui Camusso. A su vez, otros directores de cine como Lautaro Murúa, Manuel Antín, Humberto Ríos y Jorge Prelorán actuaron como asesores

\footnotetext{
${ }^{15}$ Entre otros eventos destacamos el I Congreso Nacional de Enseñanza Audiovisual (1958), los Ciclos de Difusión Cinematográfica y el Festival Internacional de Cine Infantil en 1961 y 1962.
} 
invitados. Al año siguiente comenzaron a incorporarse egresados de la Universidad del Litoral -Patricio Coll, Raúl Beceyro y Juan Oliva- apuntalando las vinculaciones regionales y otorgándole al Departamento la impronta fundada por Birri. El contexto de convulsión social y represión que afectaba al país derivaría en una politización de la escuela, y con la primera camada de egresados de Córdoba para 1971 se plantearían reformas pedagógicas.

\section{Tercera fase: politización y cierre}

La radicalización política de las tres escuelas entró en sintonía con el panorama social y cultural que atravesaba el país, y en correlato con el ámbito cinematográfico específico que entendía al film como un vehículo de acción. Recordemos sino los colectivos de realización clandestinos que, a través de posturas ideológicas diversas, llevaron a cabo un cine contrainformativo, concientizador y de denuncia. ${ }^{16}$ Dentro de este contexto advertimos que la formación técnica y profesional de las escuelas pasó a un segundo plano, cobrando importancia capital la reflexión y expresión en torno a una nueva realidad. En esta línea, el cortometraje acompañó a dicha situación emergente.

Al interior de la Universidad de La Plata, para 1970 ya se habían producido dos cortometrajes de carácter social y político: Mayo (Silvia Verga) -a partir de ilustraciones sobre la Revolución de Mayo de 1810 y un texto con alusiones al contexto de la épocay Los Taxis (Diego Eijo, Eduardo Giorello, Ricardo Moretti, Alfredo Oroz, Carlos Vallina y Silvia Verga) -manifiesto grupal de intervención política sobre el contexto argentino del momento-. Hacia 1972 estos egresados de la Carrera de Cine de La Plata comenzaron a realizar uno de los largometrajes más emblemáticos del cine militante argentino: Informes y Testimonios: La tortura política en Argentina (1966-1972). Por medio de una documentación pura y detallada, y en el cruce con reconstrucciones ficcionales que provenían de testimonios de los detenidos, la película, al mismo tiempo que denunciaba pretendía provocar un shock en el espectador. Dichos referentes de la Universidad eran militantes activos que comprendieron las circunstancias y plantearon una reestructuración de los estudios transformando el curso en un taller integral y proponiendo una "participación activa del alumno al nivel de realizaciones creativas. Haciendo del alumno un pensador responsable y comprometido con su tiempo" (Massari, Peña y Vallina, 2006: 28). La estructura abierta que ahora adquiría la carrera tenía por objetivo una toma de conciencia nacional y una liberación de la influencia colonialista en el ámbito educativo y cultural. Esta nueva forma de pensamiento conducía al artista a "rescatar los signos culturales que dan cuenta de la especificidad de lo nacional y popular, sin modelos preestablecidos" (ibídem: 31). Este deseo renovador y la búsqueda de una función social en el creador encontrarían en el cortometraje un medio efectivo de experimentación y expresión. Sin embargo, la Universidad fue una de las

\footnotetext{
${ }^{16}$ Mencionamos a los tres más destacados que influyeron de manera externa en el accionar de las escuelas: Grupo Cine Liberación -de extracción peronista-; Realizadores de Mayo -grupo heterogéneo que produjo un film colectivo acerca del Cordobazo-; Grupo Cine de la Base -cercano a las propuestas del Partido Revolucionario de los Trabajadores-.
} 
Cossalter. Del centro a la periferia. Las escuelas de cine nacionales, las rupturas del cortometraje y las nuevas formas...

primeras víctimas del terrorismo de Estado, que tenía como propósito disipar cualquier pensamiento crítico. En 1974 el Departamento de Cinematografía fue intervenido. Cesantías y persecuciones derivaron en la extinción de la carrera hacia 1976 y el cierre definitivo al año siguiente.

En Santa Fe, luego de la renuncia de Camusso asumió como director interventor del Instituto del Litoral Rodríguez Hortt, quién no tenía relación alguna con el cine. En 1971 dos proyectos - uno con connotaciones políticas- fueron censurados y como respuesta los alumnos y profesores decidieron cerrar las puertas del Instituto provocando la renuncia de Hortt. Con el advenimiento del breve período democrático en 1973 se designó a un egresado, Miguel Ángel Monte, como director del establecimiento. Para 1973/74 el compromiso político-militante podía verse reflejado en los cortos producidos, como por ejemplo Historia Argentina: la Nación Desmembrada (Dolly Pussi, 1973) y Frontera Adentro (Rolando López, 1974). Asimismo, tanto La memoria de nuestro pueblo (Rolando López, 1970-72) como Monopolios (Miguel Ángel Monte, 1975) estaban insertos dentro del peronismo de izquierda o revolucionario y a través de una propuesta estética innovadora, con intertítulos, animaciones paródicas, voces y testimonios contrainformaban y llamaban a las armas. A diferencia de las obras de Birri aquí se apreciaba un fuerte sello partidario. En 1975 removieron a Monte de su cargo. Para fines de diciembre el Instituto fue cerrado definitivamente, el personal cesanteado, el equipo técnico destruido, y la institución saqueada y desmantelada.

Por último, a comienzos de la década del setenta ya se podía percibir el carácter político en el Departamento de Cine de la Universidad de Córdoba: surgieron una serie de números de la revista Cine Documento editada por los alumnos -los primeros egresados en 1971-, que funcionó como testimonio de un contexto de reflexión y acción. Como parte de este proceso de concientización, y al igual que en la Universidad de La Plata, aquí también empezaron a cuestionarse los sistemas tradicionales de enseñanza. Entre 1971 y 1972 se produjeron cambios incorporando las modalidades de taller y modificando las formas de evaluación. En 1975, la denominada "Misión Ivanisevich" -por medio de la Ley Nacional de Intervención de las Universidades Nacionales $n^{\circ}$ 20.654- provocó el cambio de dependencia de la escuela de Artes, ahora vinculada a la Facultad de Filosofía y Humanidades, e incitó el cierre del Departamento de Cine por ser considerado subversivo. Del mismo modo que en las otras dos escuelas analizadas el personal docente y administrativo fue cesanteado, y la Filmoteca de cine, saqueada y robada, incluyendo las tesis de la primera camada de egresados.

En resumen, estas tres escuelas presentan un esqueleto de rasgos compartidos que colocaron al film breve en una posición destacada. Las relaciones con las cinematografías foráneas -ya sea por contactos en el exterior, por la formación de aquellos que habían estudiado en otros países y/o por la recepción productiva de los films extranjeros en Argentina-; la necesidad de difundir las actividades a través de festivales y encuentros diversos; los proyectos y planes de estudio organizados; la búsqueda de profesionalización mediante la incorporación de realizadores reconocidos como profesores invitados -hecho que se vería plasmado a su vez en la renovación estética 
de los jóvenes aprendices-; la adaptación a las circunstancias socio-políticas a partir de reestructuraciones de las carreras y el compromiso con la realidad circundante; y los intercambios efectivos entre las tres escuelas -egresados de una que dictaron clases en otra y la creación en los años setenta de la Coordinadora Universitaria de Cine integrada por las escuelas de La Plata, Córdoba y Santa $\mathrm{Fe}-$, permitieron que el cortometraje se erigiera no sólo como un medio de formación técnica sino precisamente en tanto dispositivo eficaz de expresión y acción, de experimentación y transformación social.

En definitiva, los cinco centros formativos y su articulación con el film de corta duración favorecieron la transición hacia el cine moderno y su asentamiento. En principio, se alzaron como espacios de producción ubicados al margen de la industria cinematográfica, tanto en su apogeo como durante su posterior declive. En segunda instancia, fomentaron la proliferación de polos de realización por fuera de Buenos Aires, abocados a temáticas locales, y generaron un entramado de relaciones entre las diversas regiones del país, hecho inusitado hasta la fecha: el Noroeste -con el Instituto de Tucumán-, el Litoral - con la escuela de Santa Fe-, el Centro Norte -con la escuela de Córdoba- y el Centro Metropolitano - con los Institutos de La Plata y Buenos Aires-. En tercer lugar, las potencialidades económicas, estructurales, estéticas y funcionales del cortometraje efectuado al interior de dichas entidades impulsaron en los textos fílmicos una marcada renovación estética así como un cambio rotundo en los modos de representación de los sectores segregados. A continuación examinaremos en un corpus de films breves estas dos tendencias de carácter moderno.

\section{EI cortometraje y la experimentación estético-narrativa}

Dentro del ámbito de la ficción, el cine clásico-industrial se caracterizó, a grandes rasgos, por el desarrollo de una narración principalmente motivada de forma compositiva y de acuerdo a las reglas del verosímil genérico adoptado. Es decir que, la coherencia que justifica la inclusión de tal o cual elemento está determinada por la relación de causa y efecto asegurando el devenir fluido de la acción dramática. En este sentido, la cámara, el montaje, el tiempo y el espacio, el estatuto del personaje -la puesta en escena en términos generales- están construidos en función de la narración. Este estilo transparente y sin fisuras en el relato, que borra las huellas del proceso discursivo con el afán de construir un mundo cerrado, se sustenta entonces en composiciones espaciales centradas, equilibradas y simétricas; una articulación entre los planos que crea una impresión de continuidad; y una narración omnisciente que delega en la causalidad de personajes que poseen objetivos claros $-\mathrm{y}$ en las convenciones del género- los componentes medulares para el avance y la resolución de la diégesis. ${ }^{17} \mathrm{De}$ este modo, la cinematografía argentina del período clásico tomó dicha matriz estética del cine hollywoodense para configurar historias nucleadas alrededor de personajesestrellas, con elementos locales como el tango y el criollismo, enmarcadas en un tinte

${ }^{17}$ Para una aproximación global a la cualidades narrativas y estéticas del cine clásico-industrial, ver: Bordwell, Staiger y Thomson [1985] (1997). 
Cossalter. Del centro a la periferia. Las escuelas de cine nacionales, las rupturas del cortometraje y las nuevas formas...

melodramático, a través de una puesta en escena que ocultaba la instancia de enunciación y una narración omnipresente y ubicua. ${ }^{18}$

Por el contrario, el punto nodal del cine moderno reside en "la autoconciencia narrativa [que] se manifestará por la presencia explícita o implícita de las marcas de enunciación de lo que ahora se asume como hecho discursivo" (Monterde, 1996: 42-43). Esta conciencia lingüística está anclada en la reflexión acerca de las formas expresivas del dispositivo fílmico. Los diferentes elementos de la puesta en escena cobran total independencia, diseñándose de esta manera un relato opaco en el cual predominan los movimientos autónomos de la cámara; un aplacamiento de la acción donde se rompe la causalidad, se diluye el clímax y se quiebra la lógica de las acciones; personajes faltos de motivos o con objetivos poco claros y rumbo incierto; y un montaje disruptivo que fractura la continuidad del canon clásico y evidencia las marcas de subjetividad. Asimismo, se abandonan los géneros en tanto tipologías normativas para encarar proyectos eclécticos y heterogéneos, que hasta incluso pueden borrar y confundir los límites entre los modelos cinematográficos. El cine moderno argentino, particularmente nucleado en derredor a los jóvenes realizadores de la Generación del sesenta, exploraron los recursos técnicos del medio cinematográfico para poner en escena los tópicos del encierro y la incomunicación a través de personajes apáticos y sin aspiraciones.

No obstante, estos rasgos modernos fueron tempranamente bien acogidos y llevados al extremo por el cortometraje, gracias a sus cualidades potenciales. En principio, el film breve se erige como un medio de expresión audiovisual singular. No se trata de un género o un formato como pretende etiquetarlo la industria del cine para encasillarlo en una fórmula fija. La multiplicidad de variantes y estilos que alberga el corto desmiente la primera acepción mientras que, en cuanto a la segunda, si bien la duración se constituye en un factor crucial el corto no se define simplemente por su aspecto longitudinal. Por otra parte, la marginalidad con respecto al sistema industrial es uno de sus valores potenciales, a partir del cual se desprenden sus posibilidades estéticas y también, como veremos en el próximo apartado, políticas. Según Paulo Pécora: "El espacio propio del cortometraje -o refugio para manifestaciones que eluden el límite de lo convencional-se encuentra esencialmente en los suburbios de esa extensa urbe industrial que es el cine comercial" (2008: 381). Esta falta de rentabilidad que ha determinado su corrimiento fuera de los bordes del cine canónico le ha concedido una independencia económica que se traduce concretamente en una mayor libertad estética. Como bien señala Guadalupe Arensburg: "Libre de las leyes del mercado con sus estrictos condicionamientos comerciales los cortos son un producto casi marginal (...) siendo el espacio idóneo para la búsqueda de formas alternativas de lenguaje, de nuevos temas, persiguiendo la experimentación y la innovación (Fernández y Vázquez, 1999: 155). Entonces, esta libertad estética se traduce no sólo en la búsqueda de nuevos lenguajes sino también en la viabilidad para encarar temáticas poco transitadas. Dentro de este contexto de amplias perspectivas formales y semánticas el séptimo arte

\footnotetext{
${ }^{18}$ Con el objetivo de profundizar sobre las características del cine clásico argentino se recomienda la lectura de: España (2000).
} 
encuentra en el corto un resquicio propicio para pensarse a sí mismo. En este sentido, la autorreflexión y autoconciencia propias de la modernidad cinematográfica pueden ser aprehendidas y fortalecidas por dicho medio expresivo. A su vez, la estructura del corto presenta algunas especificidades. Su duración acotada vertebra la organización interna del relato. Concordamos con Paulo Pécora cuando afirma que "hay quienes piensan el tiempo como una limitación, pero la brevedad en realidad funciona a la inversa, porque ayuda inevitablemente a ajustar y direccionar la creatividad" (2008: 383). Es decir que el corto no es un pequeño largo. Se produce siempre una adecuación de la acción filmada a la duración. Asimismo, en el cortometraje se suelen condensar, concentrar y comprimir los tiempos y las acciones, así como la reducción -tanto de la historia como de los personajes- se transforma en una noción clave dentro de la tendencia ficcional. Esta alberga generalmente una trama simplificada y pocos personajes presentados en la acción (Cooper y Dancyger, 1998), un conflicto que se exhibe tempranamente, menos subtramas y diálogos cortos con más subtextos (Ickowicz, 2008). Ahora bien, estos lineamientos pueden ser deconstruidos a partir de la experimentación inherente al corto y en presencia de una propuesta modernista. Así, la intensidad puede desaparecer junto con las acciones en el seguimiento de personajes que deambulan sin objetivos claros o procesos que no concluyen en transformaciones reconocibles. Por último, y debido a la conjunción de esta condición estructural y las libertades señaladas, el modo de articulación entre las bandas de imagen y de sonido puede volverse reflexivo y evidenciar el artificio a través de la ausencia de diálogos, la utilización marcada y autónoma del sonido, y la puesta en relieve de los aspectos visuales y perceptuales.

A partir de los rasgos del cine moderno mencionados y las cualidades potenciales del cortometraje analizaremos un corpus de films breves concebidos al interior de las escuelas de cine, teniendo en cuenta tres rangos de contraste que se convirtieron en pilares de la modernidad cinematográfica local: la hibridación de modelos -el borramiento intencional de los límites entre las tipologías de ficción, documental y experimental-, la autorreflexión del medio expresivo -la puesta en evidencia de artificio- y la explicitación de las huellas enunciativas -bajo la presencia manifiesta del meganarrador o la inscripción material de la subjetividad del personaje-.

La hibridación de modelos cinematográficos adoptará diversas variantes y articulaciones en las obras del corpus. La verdadera historia de la primera fundación de Buenos Aires (Fernando Birri, 1959), realizada dentro del Instituto de Cinematografía de la Universidad Nacional del Litoral, a partir de un cuadro del pintor argentino Oski (Oscar Conti) como único elemento visual y a través del testimonio de Ulrico Schmidl que es relatado por una voz over, narra la expedición de Pedro de Mendoza en el SXVI. El propio Fernando Birri ha pensado a este film como una obra experimental, y en parte lo es. Sin embargo, su forma y sustancia expresiva, y la materia del contenido dejan entrever una mixtura de registros, modelos y finalidades. Como parte de la reflexión en torno a la mezcla entre lo documental y lo ficcional en la obra de Birri, y a propósito de este film, María Aimaretti, Lorena Bordigoni y Javier Campo expresan que "es una forma de registro de la realidad, de la superficie del cuadro, a la vez que, mediante el 
montaje y la voz over, construye una narración y una temporalidad ficcional" (2009: 379). De este modo lo documental aparece como registro e intencionalidad, gracias a la voz over y la perspectiva de revisión histórica del pasado, mientras que el ojo de la cámara y el montaje -entre planos e interno al cuadro fílmico- se constituyen en tanto principios estructurales que le imprimen al cuadro una espacialidad y temporalidad cinematográfica. Estos recursos son los responsables de la impronta ficcional que alcanza el relato. Por su parte, la imbricación de los tres modelos de ficción, documental y experimental tomará una forma singular en Cirugia (Luis Vesco, 1960), producido en la Escuela de Cine de la Universidad Nacional de La Plata. Este breve relato de cinco minutos condensa el proceso global de una operación de úlcera de estómago que se extendió por dos horas pero cuyo recorte se presentó en este intervalo reducido. $\mathrm{La}$ operación, los médicos y la paciente son reales -pertenecen al enfoque documental-; los enfermeros que entran y sacan a la paciente son actores; el montaje, la cámara y el encuadre son experimentales, como lo es asimismo el proyecto en sí cuyo propósito expresivo trasciende los fines divulgativos y científicos propios del registro tradicional de una operación. Dimensión (Aldo Luis Persano, 1960), concebido en el marco del Instituto Cinematográfico de la Universidad de Buenos Aires, desarrolla durante nueve minutos un registro visual de esculturas móviles de Mauro Kunst -diseñador y arquitecto radicado en Argentina por aquellos años-. Sin embargo, el film no puede ser considerado como un mero registro documental de una obra artística ya que la puesta en escena, por momentos cerca de la pura abstracción, y el despliegue explícito de los recursos cinematográficos, se colocan por encima del objeto representado, otorgándole al texto fílmico una impronta claramente experimental. Por último, a diferencia de estos tres cortos que se ubican en una primera etapa de transición y asentamiento del cine moderno, Single -un ejercicio incompleto- (Alberto Yaccelini, 1967 [1970]) demuestra cómo la exploración estética se ha sostenido en el tiempo, hasta incluso de modo radicalizado con el paso de los años. Este cortometraje, oriundo de La Plata, entrelaza de forma reflexiva los tres modelos cinematográficos. El director tenía el proyecto de rodar un film que tuviera como protagonista al singlista campeón mundial Alberto Demidi. La propuesta en principio era conformar un film argumental realista sobre el carácter solitario del remo pero Demidi no cooperó por lo que el cineasta decidió encararlo como un documental. De este modo, según la voz en off de uno de sus ayudantes, trabajaron hasta que agotaron el material virgen brindado por la escuela, entonces "el material quedó incompleto". Otro de los técnicos comenta que en ese momento surgió la idea de "hacer una especie de anticine con una serie de elementos heterogéneos" -una idea, cartas, fotos de la filmación, el material filmado-, pero que según su apreciación tampoco pudo lograrse. Ahora bien, es en realidad esta tercera opción, la experimental, aquella que constituye el discurso final plasmado en el relato.

La autorreflexión del medio expresivo -que se apoya también en esta imbricación de modelos- está anclada en la autoconciencia del lenguaje cinematográfico y del propio dispositivo. La verdadera historia... pone en evidencia las potencialidades de la cámara y el montaje para conformar una narración audiovisual a partir de una materialidad particular: imágenes fijas de una pintura. El testimonio en over colaborará 
para generar situaciones conflictivas y de tensión. En primer lugar, rescatamos una serie de barcos en el agua que apuntan hacia el margen derecho, y la cámara que barre en sentido opuesto con la intención de simular el movimiento real. Por ejemplo, otro modo de engendrar el progreso narrativo consiste en presentar un montaje sucesivo de planos fragmentarios que, gracias al relato en over, obtienen unidad y temporalidad: la secuencia que narra cómo los indios querandíes cazan su presa, la juntan y beben su sangre es exhibida a través de tres recortes diferentes del cuadro. Otra forma de producir una sensación de movimiento mediante el montaje radica en fragmentar en dos primeros planos los componentes de una misma acción: el indio dispara una flecha y en el plano siguiente vemos el impacto de esta. A su vez, se recurre al montaje alterno entre un fragmento que aúna a los querandíes y otro que reúne a los soldados españoles para fabricar el enfrentamiento. En Cirugía, nuevamente la cámara, el encuadre y el montaje sobresalen como procedimientos centrales, en esta oportunidad, para construir una cronología lineal de la operación tomando fragmentos de los distintos momentos cruciales del evento, desde la entrada del paciente consciente hasta el fin de la cirugía. El diálogo de fondo de los médicos y el sonido ambiente confrontan con la cercanía a través de la cual la cámara se emplaza a lo largo del corto. La operación es visualizada a partir de encuadres cerrados y primeros planos que permiten focalizar y detenerse en las distintas acciones y elementos que intervienen en la misma. La imagen inicial del instrumental es seguida por un primerísimo plano de los ojos de la paciente cuya estética pareciera aproximarse a la del género de terror. Esta forma de encuadrar las imágenes se conjuga con una iluminación exigua que genera un espacio abstracto, difuso, en el cual irrumpen sombras expresionistas y superficies reflejantes que producen deformaciones surrealistas. Esta heterogeneidad de estilos junto con una puesta en escena autónoma y marcada denotan la presencia explícita del dispositivo. Por otro lado, en Dimensión los elementos escultóricos-artísticos que el cortometraje convoca no interfieren en la reflexión del medio expresivo. Los componentes centrales del dispositivo se revelan en todo su esplendor: luz, movimiento, tiempo, espacio y sonido. La narración aquí es inexistente, sólo asequible en tanto desarrollo temporal-material. El corto se inicia con una toma fija sobre un objeto colgante que se mueve en su eje, poco iluminado y sobre fondo negro, proseguido por un travelling que recorre cuerpos móviles similares. Esta tenue luminosidad sólo nos permitirá percibir fragmentos de los elementos pero no su composición global. La indeterminación espacial producto de esta iluminación exigua y la falta de referencias tradicionales son acompañadas por una música de tipo concreta y por momentos disonante, que funciona como sistema significante autónomo aunque se encuentra en sintonía con el marco de abstracción que suscitan la luz, el espacio y el movimiento. A su vez, un montaje encadenado permite pasar, cuando no es utilizado el travelling, de una escultura a otra sin percibir el corte, hecho que configura una temporalidad dilatada y sostenida, inclusive abstracta -conciencia de un tiempo estético-. Finalmente, Single... lleva al extremo la reflexión sobre el medio, poniendo al descubierto el artificio. El ensayo experimental, es decir la propuesta de anticine, no sólo cuenta la historia de los proyectos fallidos sino que articula en un nuevo nivel discursivo elementos de la veta documental -las imágenes de registro del remero-, del 
Cossalter. Del centro a la periferia. Las escuelas de cine nacionales, las rupturas del cortometraje y las nuevas formas...

proceso metatextual -las fotos fijas del rodaje y las cartas de disculpa de Demidi-, y también de la línea argumental, ya que la soledad del singlista que se pretendía retratar se traslada a la actitud del cineasta que, de forma solitaria y contra todas las vicisitudes, se repone del fracaso para construir un film armónico y unitario que no habla tanto del remo sino del quehacer cinematográfico. Entonces, no sólo se combinan elementos y recursos de la ficción y el documental sino que de forma experimental se reflexiona sobre aquellos.

Si bien las huellas enunciativas se explicitan en los cortos analizados a través de los movimientos de cámara constantes y autónomos, los encuadres pronunciados, el montaje marcado de diversas materialidades y los cambios de iluminación, hay un ejemplo de neto corte ficcional que, de forma análoga a los largometrajes modernos locales, entrelazará la proyección de la subjetividad del personaje protagónico en la banda visual con la presencia evidente del meganarrador: Lucho Robledo (Diego Eijo, 1965). En este film breve producido por la Universidad de La Plata el conflicto se presenta de forma temprana y los diálogos son relativamente cortos -rasgos potenciales del cortometraje ficcional-. Lucho Robledo es un obrero que trabaja en una fábrica y que fantasea con ser cantor de tango. En camino a su trabajo compra la revista Tanguera y ve el anuncio de un concurso de nuevas voces del tango. Acto seguido se suceden los créditos del film intercalados con planos congelados del protagonista en traje y con mímica de canto. En principio, se trata de un gesto de autoconciencia enunciativa; la narración se manifiesta como tal. Sin embargo, de forma retrospectiva podemos ir más allá en el análisis y asignarle a dichos fotogramas el carácter de flashforward, es decir, imágenes que corresponden a un acontecimiento futuro en la diégesis. Ahora bien, este suceso no tendrá lugar en el plano real de la ficción sino que se tratará de una imagen mental del personaje. En este sentido, en términos enunciativos, la vinculación entre la realidad y el ensueño, entre las marcas del personaje y las huellas del narrador en el relato, exhibirán un alto grado de opacidad. Durante el trabajo el personaje repara en la revista e inmediatamente nos transportamos a un tiempo-otro, el de la ensoñación: por medio de encuadres en picado del público en un teatro y contrapicados del presentador y de Lucho se nos anuncia a este como ganador del concurso de nuevas voces del tango. Ahora bien, la relación entre la fantasía y la realidad se vuelve significativa cuando los compañeros lo instan a Lucho a hablarle al patrón por un aumento, momento en el que se rompe una de las máquinas que operan. En definitiva, este corto articula las problemáticas subjetivas - propias de la narración moderna-e individuales de un obrero con la insatisfacción laboral. Allí el mundo del tango aparece como un espacio de escape y liberación frente a la apatía y la infelicidad que el empleo provoca en el protagonista. Esta leve crítica en la exposición de las condiciones laborales nos da el puntapié para continuar con el análisis de la representación moderna de los sectores populares y la clase trabajadora. 


\section{El corto moderno y los matices críticos en la representación de los sectores subalternos}

Los films de ficción argentinos durante el período clásico se erigieron como un cine popular no sólo por su estructura industrial y masiva sino también de acuerdo al contenido y las temáticas abordadas. Desde películas iniciales como ;Tango! (Luis Moglia Barth, 1933) y Los tres berretines (Lumiton, 1933) la cinematografía local puso en escena a los sectores populares - principalmente urbanos- a partir de aquello que Alicia Aisemberg define como "prácticas misceláneas" (2009: 210), es decir, la articulación de formas y discursos heterogéneos provenientes del sainete, el tango, el cine, el deporte y la revista porteña. Generalmente dichas representaciones de la cultura popular estaban tamizadas a través de un enfoque relativista, también denominado populista (Grignon y Passeron, 1991). Esta perspectiva se caracteriza por resaltar únicamente los valores positivos de la cultura popular y ocultar las relaciones de dominación. ${ }^{19}$ Asimismo, estas producciones que apelaban al sentimentalismo y a una estructura melodramática no se mostraron permeables al contexto socio-político del momento. Empero, existió otra vertiente preponderante que Ana Laura Lusnich (2007) acuñó como drama social-folclórico, donde el universo rural era representado de manera realista, exhibiendo los conflictos de sujetos anclados en la periferia. No obstante, la denuncia social estaba matizada por el entramado melodramático y el corrimiento de la acción hacia un tiempo pasado. ${ }^{20}$

Hacia finales de los años cincuenta, de la mano de una intencional reacción antipopulista, surgieron una serie de films como Detrás de un largo muro (Lucas Demare, 1958) y El jefe (Fernando Ayala, 1961), cuya postura en relación a la cultura popular sería continuada por el cine moderno ficcional de la Generación del sesenta (Cartoccio, 2007). Allí se perpetraba la posición opuesta al relativismo que Gringnon y Passeron etiquetan como legitimista, donde su versión extrema desemboca en el miserabilismo. Esta reconoce a los sectores populares como dominados pero en tanto un campo social homogéneo en el cual las diferencias se perciben como carencias, excluyendo a estos de la dimensión simbólica de la cultura. Ahora bien, será en la rama documental de corte social y político, gestada a finales de los cincuenta y radicalizada en torno a mediados de los sesenta, que podremos apreciar una perspectiva intermedia en derredor a la representación de los sectores populares comprendidos, en términos de Antonio Gramsci (1981), como grupos subalternos donde el subalterno es el otro inferiorizado producto de un proceso político hegemónico. En total concordancia con Silvana Flores, "a diferencia de lo que acontecía con el cine volcado a las reivindicaciones de los trabajadores durante el período clásico-industrial, los agentes productores del cine político de la modernidad modificaron las estructuras industriales, de recepción y de elaboración de sus espacios y personajes, con el objetivo de producir una activación política en los realizadores y espectadores" (2013: 448). El enfoque adoptado en esta tendencia -que anclaba sus

\footnotetext{
${ }^{19}$ De un modo similar, el documental institucional durante los años cuarenta y cincuenta ensalzaba a la clase trabajadora rescatando sus virtudes, en este caso, gracias a las condiciones ofrecidas por el gobierno peronista.

${ }^{20}$ En esta tendencia sobresalen, entre otros films, Prisioneros de la tierra (Mario Soffici, 1939) y Las aguas bajan turbias (Hugo del Carril, 1951).
} 
Cossalter. Del centro a la periferia. Las escuelas de cine nacionales, las rupturas del cortometraje y las nuevas formas...

propuestas en objetivos políticos concretos como la denuncia, la concientización y la agitación- se sustentaba en el reconocimiento de la cultura popular como tal, múltiple y heterogénea, y colocaba el acento en su relación conflictiva con lo dominante. Esta posición crítica, sostenida por Pablo Alabarces (2002) entre otros, está centrada en la noción de hegemonía que impacta en los sectores populares en tanto espacios plurales que manifiestan particularidades culturales. En palabras del autor: "el pueblo no existe como tal, no existe algo que podamos llamar pueblo, no existe algo que podamos llamar popular como adjetivo esencialista, pero lo que existe y seguirá existiendo es la dominación y esa dominación implica la dimensión del que domina, de lo dominado, de lo hegemónico y de lo subalterno. Eso es lo popular: una dimensión simbólica de la economía cultural que designa lo dominado" (2002: 7).

Dicha transformación en la perspectiva ideológica dentro del cine moderno estuvo parcialmente impulsada por las potencialidades del cortometraje, en el marco de la formación material y social apre(he)ndida en las escuelas. En principio, la marginalidad del corto le permite al cineasta asumir riesgos no sólo formales sino asimismo en términos del contenido escogido y el punto de vista de abordaje. La libertad creativa se traduce aquí también en una ampliación semántica y pragmática. Por otro lado, la condensación y concentración del tiempo y de la acción posibilitan que la estructura del film breve establezca una relación singular con el receptor. Como expresan Mariangel Bergese, Isabel Pozzi y Mariana Ruiz: "Las imágenes que actúan como flashes de información llegan al espectador de una manera distinta a la de un largo (...) el espectador del corto adopta una actitud diferente ante lo que ve, porque prevalece en él la idea de fugacidad que lo obliga a mantener una atención constante" (1997: 65). Ahora bien, estos caracteres se potencian en el vínculo con el modelo documental, y sobre todo, con la tendencia del cine social y político en donde la marginalidad, el bajo presupuesto, la efectividad y la relación inmediata con el receptor cobran particular eficacia. En este sentido, el corto se convierte en un "espacio de resistencia" (Pécora, 2008: 380). La noción de un espectador activo resulta medular en dicha corriente fílmica. Esta efectividad que mantiene el corto en su relación con un receptor al cual se pretende alcanzar mediante los objetivos mencionados despierta en él procesos de reflexión que van a continuar en su mente. Aquí subyace la utilidad social del dispositivo y sus implicancias extra-cinematográficas (Velleggia, 1986).

El corpus de cortos seleccionado para el análisis evidencia un eclecticismo de estrategias formales y modalidades de acercamiento hacia los sectores populares, recursos que van desde la ficcionalización de situaciones, pasando por la cámara observadora, el uso de testimonios, intertítulos y animaciones. Dichos procedimientos modernos acompañan y sustentan los fines políticos acogidos. A su vez, este enfoque que privilegia la heterogeneidad cultural de los sectores populares se vincula estrechamente con la descentralización de la producción y el rescate de identidades locales y regionales puesto en marcha por las escuelas de cine de universidades nacionales.

Ahora bien, con el propósito de asentar la premisa acerca del papel de transición de las escuelas de cine debemos comenzar explorando la representación de los sectores 
populares en el Instituto Cinefotográfico de la Universidad Nacional de Tucumán puesto que, debido al arco temporal de su desarrollo, este produjo cortometrajes de corte clásico y de carácter moderno. Es decir, en relación a los sectores populares manifestó perspectivas populistas y posiciones críticas, inclusive sin plegarse a la politización que caracterizó a los otros centros formativos. Quizás la presencia de la primera tendencia se deba asimismo al enfoque científico y pedagógico adoptado por el Instituto desde el inicio. La primera realización de la entidad, La Universidad de Tucumán es "Una institución en marcha” (Héctor Peirano, 1947), se trata de un documental institucional que efectúa un racconto de los diferentes hitos destacados desde el nacimiento de dicha universidad. Durante ese recorrido se detiene en varias oportunidades en el aporte universitario hacia diversas ramas dentro del sector del trabajo. Por ejemplo, en torno a los trabajadores de la zafra, una descripción visual de su labor es acompañada por una voz over que resalta las cualidades prodigiosas de la tierra y "las cosas que contribuyen a la riqueza del país". En este sentido, el trabajador es considerado una pieza que encaja en ese circuito productivo. A su vez, en derredor a la creación del Instituto Técnico el narrador sostiene que el aspirante "entra de lleno en el oficio elegido" y adquiere en poco tiempo "confianza en sí mismo y habilidad en el trabajo que ha de hacerlo un hombre útil". De esta forma la clase trabajadora es presentada en total integración y comodidad con respecto al sistema capitalista. De modo más claro puede apreciarse esta postura populista en un docudrama del mismo año y director: Acridio. Allí se relata la lucha que realiza el campesino frente a la invasión de langostas. Es nuevamente la voz over la encargada de marcar el rumbo. Esta pone el foco en "la riqueza del vasto suelo patrio" y en la pareja de trabajadores sonriendo, ya que "con el amor se sobrellevan airosamente las fatigas". El marido y la mujer, abrazados y sonrientes, ven "el anhelo cristalizado": el cultivo. Si bien la plaga de langostas es una amenaza efectiva, que destruye el trabajo, esta es sofocada por el trabajo conjunto de los vecinos y "una brigada de lucha con modernos equipos". En definitiva, el esfuerzo colectivo lleva al "orgullo de ser hijos de esta tierra". En este corto, incluso un ataque externo no desestabiliza la alegría de los campesinos cuya dedicación y esfuerzo son el bien más preciado.

Por el contrario, Casabindo (Jorge Prelorán, 1965), concebido dentro del Instituto de Tucumán y bajo un convenio con el Fondo Nacional de las Artes, exhibe una serie elementos formales y semánticos que nos permiten desentrañar el pasaje del paradigma clásico al moderno, y del enfoque populista a un punto de vista que, aunque revaloriza a los sectores populares, evidencia de forma crítica la marginalidad y el desequilibrio. Si bien la voz over informativa no desaparece, lo novedoso resulta de la incorporación de una voz subjetivada y la función de una cámara autónoma que observa el paisaje y los personajes del lugar. Ahora bien, desde el comienzo esa narración institucional particulariza geográficamente el espacio de la acción -el pueblo de Casabindo ubicado en la puna jujeña del norte argentino- y a diferencia de los cortos anteriores focaliza en las dificultades que provienen, en esta oportunidad, del carácter árido y desértico de la zona. El narrador certifica aquello que la cámara devuelve, por medio de travellings y panorámicas, en imágenes: "pueblos como Casabindo que viven y están muriendo". Luego esa voz impersonal con tono neutral deja lugar a una voz personalizada, como si su 
Cossalter. Del centro a la periferia. Las escuelas de cine nacionales, las rupturas del cortometraje y las nuevas formas...

portador fuera parte de la comunidad sobre la cual profiere sus palabras. Esta expresión verbal determina un cambio en la postura de la cámara, la cual adopta una posición más cercana a los hechos: planos cercanos y fragmentarios sobre los pueblerinos que se congregan alrededor de Nuestra Señora de la Asunción durante la festividad anual. De esta forma el corto intenta rescatar y revalorizar la identidad de un pueblo singular del norte argentino, no sin enfatizar la marginalidad y el abandono que sufre. Como expresa la voz narradora al concluir: "Termina la fiesta y Casabindo se apaga otra vez". En definitiva, al mismo tiempo que se valorizan las riquezas culturales del poblador local se pone críticamente de manifiesto su segregación. De un modo similar, Fiesta en Sumamao (Aldo Luis Persano, 1961) expone ciertos rasgos modernos y una postura también crítica frente al olvido de un pueblo. Este fue ideado en el Instituto de Cine de la Universidad de Buenos Aires -tampoco acoplado a la politización radical- aunque está concentrado en una población de la provincia de Santiago del Estero, y a modo de prólogo la instancia enunciadora dedica el film a los niños de Santiago mediante primerísimos planos a los rostros de estos niños que miran a cámara. Al igual que en el corto de Prelorán la voz narradora nos sitúa en la geografía del lugar planteando las adversidades naturales: "Sumamao es una antigua población de la provincia de Santiago del Estero situada a orillas de un brazo muerto del cambiante río dulce. Allí donde ya no hay cosechas". Una vez al año la festividad le aporta vitalidad a un pueblo marginado. Luego de capturar la ceremonia, la voz over concluye aseverando que la festividad con sus tradiciones resiste dentro de un pueblo conquistado; se erige sobre formas impuestas y jerarquías con las que se pretendió quebrantarlo. La revalorización de la comunidad y la crítica a la marginalización son los objetivos de este cortometraje.

No obstante, como ya anticipamos, fue en el Instituto de Cinematografía de la Universidad Nacional del Litoral donde se evidenciaron fuertes rupturas expresivas modernas y matices políticos radicales en torno a los sectores populares ya desde finales los años cincuenta. Tire dié (Fernando Birri, 1958[1960]) formula una denuncia explícita del subdesarrollo en la provincia de Santa Fe a partir de una participación activa de los sujetos populares y la captura del ritual diario en donde los niños se acercan a las vías del tren para pedir una moneda a los pasajeros. Luego de un prólogo que parodia al típico documental institucional que otorga datos sobre la economía capitalista, el corto cede la voz a los lugareños que toman la palabra para exponer su situación laboral: "nunca pude tener nada, y ahora menos que antes"; "no se consigue trabajo en Santa Fe"; "la jubilación la estamos esperando hace seis años"; "me gano la vida lavando y me pagan cuatro pesos por sábana", son algunos de los ejemplos. ${ }^{21}$ Acto seguido vemos las imágenes de los niños recolectando el dinero que le arrojan los pasajeros del tren, y que muchas veces alcanza para que coma una familia entera. De este modo el film enfatiza en la noción de dominación y el carácter subalterno de los sujetos abordados, así como manifiesta la heterogeneidad de los sectores populares mediante los diversos testimonios particulares. Por otra parte, a través de una estrategia diferente, el Instituto produjo Los 40 cuartos (Juan Oliva, 1962), corto documental que incorpora una línea

\footnotetext{
${ }^{21}$ Debido a que la banda sonora era ininteligible, en la versión final se doblaron las voces testimoniales.
} 
narrativa ficcional para dar a conocer y denunciar el problema de la vivienda en la provincia de Santa Fe. El cuerpo principal del film está centrado en revisar las pésimas condiciones de vida de los inquilinos del conventillo más grande de la provincia. A partir de preguntas a modo de encuesta, que se explicitan por medio de una voz over, residentes de los diferentes cuartos exponen las problemáticas edilicias y habitacionales así como sus preocupaciones familiares. Estas escenas están organizadas alrededor de una autoconciencia enunciativa donde la cámara realiza movimientos evidentes que describen las condiciones de inhumanidad a las que están sometidos los sujetos abordados. Luego, el conflicto dramático se nuclea en torno a una joven pareja que, frustrada por no encontrar un alquiler al alcance de sus posibilidades económicas, desemboca en el conventillo aludido. Las últimas tomas elaboran una visión global de la vida en este conventillo por medio de una cámara que se posa en la cotidianeidad de algunas familias al interior del mismo. Aquí también se repara entonces en las múltiples singularidades que caracterizan a estos sectores populares, marcando la dimensión conflictiva de la marginalidad a través de los testimonios y una cámara autónoma que muestra el espacio como una serie de postales de la miseria y el abandono.

Dentro de la Escuela de Artes de la Universidad Nacional de Córdoba hubo asimismo una preocupación por reflexionar acerca de los sectores populares a través del rescate de comunidades locales. Este es el caso de Ceramiqueros de Traslasierra (Raymundo Gleyzer, 1965), centrado en una comunidad de alfareros ubicada en los alrededores de Mina Clavero. De forma análoga a los films examinados, este corto se organiza en torno a la observación y el testimonio. El relato se enfoca en el personaje de Alcira López. Las preguntas de la periodista y las respuestas de Alcira sobre las especificidades y el desarrollo de la alfarería se reflejan en las imágenes de los propios lugareños realizando dichas acciones mediante una cámara que observa de manera autoconsciente las diversas situaciones. Si bien el hecho de registrar y poner al descubierto la vida de la comunidad es uno de los propósitos del film, la incorporación del testimonio como motor de la identidad de este sector popular está en función de generar una crítica concreta al abandono de dicha comunidad marginada. Esto se manifiesta claramente en el discurso de la entrevistadora que comienza preguntándole a Alcira si les alcanza para vivir y concluye el film con el interrogante acerca de si cree que con esta película van a poder ayudarla, a lo que ella responde que tal vez, pero que hasta ahora nadie los ha ayudado. Este gesto metatextual -que se completa con el inserto de dos fotografías del equipo de rodaje dentro de la colectividad-marca la postura de la instancia productiva, que se coloca cerca de la comunidad para descubrir su cultura específica y con el objeto de incidir sobre su condición de marginalidad.

Finalmente, Monopolios (Miguel Ángel Monte, 1975), último film realizado por el Instituto de Cinematografía de la Universidad Nacional del Litoral antes del cierre definitivo, corrobora el asentamiento de las propuestas modernistas y la perspectiva crítica a lo largo de las décadas. El film breve aglutina diferentes procedimientos de autoconciencia enunciativa para denunciar los estragos del capitalismo y concientizar al pueblo trabajador convocándolo a la lucha activa. El relato se inicia con imágenes de 
Cossalter. Del centro a la periferia. Las escuelas de cine nacionales, las rupturas del cortometraje y las nuevas formas...

pobreza y miseria de los trabajadores, mostrando la precariedad del rancho y el basural a su alrededor, mientras que en contrapunto una canción "agradece al señor por un nuevo día y por la esperanza". Luego, repentinamente, diversos intertítulos sobre fondo negro hacen su aparición a modo de shock como respuesta a la voz over que pregunta " ¿a qué se debe la pobreza?": "Al imperialismo capitalista"; "Al colonialismo económico y cultural"; "A los monopolios". Acto seguido, esta voz narradora describe de forma pedagógica el accionar del capitalismo en nuestro país a través de una clara referencia al marxismo, que se completa con un dibujo animado paródico e irónico acerca de los monopolios y el imperialismo. Asimismo, la voz en off de un trabajador, que luego se presenta ante la cámara, explica una vez más los problemas del capitalismo en Argentina, que se generan como consecuencia de la operatoria de grandes empresas nacionales y multinacionales gracias a las cuales "unos pocos se enriquecen mientras un pueblo va desfalleciendo y se va empobreciendo día a día". En definitiva, este corto pone el acento de manera radical en esclarecer las relaciones de dominación y su impacto en la clase trabajadora, a la cual pretende movilizar mediante un discurso crítico y efectista.

\section{Conclusiones:}

En el presente artículo hemos pretendido estudiar el papel de las escuelas de cine y el cortometraje en la transición del paradigma clásico al moderno, y en el posterior asentamiento de la modernidad cinematográfica local. Frente al cine clásico concebido de forma industrial y centralizada en Buenos Aires, las escuelas de universidades nacionales ampliaron el rango geográfico de producción y promovieron un cine no comercial que renovaba las formas expresivas y el campo semántico. Allí el cortometraje, gracias a sus potencialidades estéticas y estructurales, se convirtió en una herramienta privilegiada de aprendizaje y experimentación así como también en un vehículo de acción social. De este modo, exploramos en un primer apartado el desarrollo histórico de las cinco escuelas destacadas durante esta etapa: el Instituto Cinefotográfico de la Universidad Nacional de Tucumán, la Escuela de Cine de la Universidad Nacional de La Plata, el Instituto de Cinematografía de la Universidad Nacional del Litoral, el Departamento de Cine de la escuela de Artes de la Universidad Nacional de Córdoba y el Instituto de Cine de la Universidad de Buenos Aires. En esta sección prestamos atención a las periodizaciones internas -el surgimiento temprano del Instituto de Tucumán; las fases de profesionalización y politización en los centros de Santa Fe, Córdoba y La Plata-, los intercambios entre las entidades, la circulación de directores-docentes, los contactos con el exterior y la permeabilidad al contexto social. Luego, con el objeto de corroborar las marcas modernas en el corto de las escuelas examinamos dos corpus de films breves para detenernos en los procedimientos estéticos abordados y en las modalidades de representación de los sectores populares, respectivamente. En este sentido, observamos por un lado una autorreflexión del medio expresivo, mediante la explicitación de las huellas enunciativas y la hibridación de modelos cinematográficos, y por el otro una postura crítica y de denuncia en torno a las condiciones de vida de sectores subalternos específicos, que reconoce la dimensión conflictiva de dominación. Ambas estrategias 
rompen tanto con la transparencia del relato como con el enfoque populista, rasgos característicos del cine clásico.

Para concluir, señalamos la pertinencia de los objetivos de este ensayo y abrimos el panorama para futuras investigaciones. En primer lugar, el cortometraje es generalmente considerado como un medio subsidiario y no en tanto gestor y/o promotor del cine moderno. El análisis histórico y fílmico que desarrollamos en este trabajo justifica esta última premisa. En segunda instancia, la reflexión articulada en torno a las escuelas permite matizar las periodizaciones tradicionales y abandonar el corte tajante entre la cinematografía clásica y moderna para pensar la idea de una convivencia y un traspaso gradual. Finalmente, la apertura geográfica en la manufactura del cine argentino, el fuerte énfasis colocado en temáticas y problemáticas localistas/regionalistas, y las relaciones e intercambios entre las diversas regiones o sectores productivos son cualidades novedosas activadas por las escuelas y el cortometraje que, tiempo después, se afianzarían como prácticas corrientes. Luego de este impulso dinamizador inicial resultaría relevante desentrañar la evolución de dichas vinculaciones desde la finalización de la etapa moderna en adelante, reparando en posibles continuidades y rupturas, así como también sería trascedente conocer el rol actual de las escuelas de cine en el surgimiento y establecimiento de los nuevos polos regionales de producción audiovisual.

\section{Referencias bibliográficas}

Aimaretti, M., Bordigoni, L. y Campo, J. (2009). "La Escuela Documental de Santa Fe: un ciempiés que camina". En Lusnich, A. L. y Piedras, P. (Ed.), Una historia del cine político y social en Argentina: formas, estilos y registros (1896-1969). Buenos Aires: Nueva Librería.

Aisemberg, A. (2009). "La redefinición de los personajes en el cine social del período clásico-industrial”. En: Lusnich, A. L. y Piedras, P. (Ed.), Una historia del cine político y social en Argentina: formas, estilos y registros (1896-1969). Buenos Aires: Nueva Librería.

Alabarces, P. (2002). "Cultura(s) [de las clases] popular(es), una vez más: La leyenda continúa. Nueve proposiciones en torno a lo popular". En VI Jornadas Nacionales de Investigadores en Comunicación. Córdoba: Universidad Nacional de Córdoba.

Bergese, M., Pozzi, I. y Ruiz, M. (1997). “Anatomía de cuerpos menudos. Sobre el pasado y el presente del cortometraje nacional". Ossessione, 1, 65-66.

Bilbao, S. y Robles, N. P. (2011). "Vanguardia, Universidad y Cinematografía: La experiencia del Instituto de Cine de la Universidad de Buenos Aires". En Actas IX Jornadas de Sociología. Capitalismo del siglo XXI, crisis y reconfiguraciones. Luces y sombras en América Latina. Buenos Aires: Universidad de Buenos Aires.

Birri, F. (1964). La escuela documental de Santa Fe. Santa Fe: Prohistoria Ediciones.

Bordwell, D., Staiger, J. y Thomson, K. [1985] (1997). El cine clásico de Hollywood. Estilo cinematográfico y modo de producción hasta 1960. Barcelona: Paidós Ibérica. 
Cossalter. Del centro a la periferia. Las escuelas de cine nacionales, las rupturas del cortometraje y las nuevas formas...

Cartoccio, E. (2007). "Realismo y representación de los sectores populares en el cine de la 'generación del 60'. El caso de Los inundados". En Papeles del CEIC, 2, 1-36.

Ceccato, G. y Maina, M. (1990). "El Instituto de Cinematografía de la Universidad Nacional del Litoral”. En Cuadernos del INCERC. Paraná: Universidad Nacional de Entre Ríos.

Cooper, P. y Dancyger, K. (1998). El guión de cortometraje, Madrid, Instituto Oficial de Radio y Televisión.

Grignon, C. y Passeron, J. C. (1991). Lo culto y lo popular. Miserabilismo y populismo en sociología y literatura. Buenos Aires: Nueva Visión.

Díaz Suárez, N. y Enrico, A. (2006). "Instituto Cinefotografico UNT (ICUNT). Apuntes para una historia II". En Actas del Primer Congreso sobre la Historia de la Universidad Nacional de Tucumán. San Miguel de Tucumán: Universidad Nacional de Tucumán.

España, C. (Comp.) (2000). Cine Argentino: industria y clasicismo / 1933-1956. Buenos Aires: Fondo Nacional de las Artes, Vol. I.

España, C. (Comp.) (2005). Cine argentino, modernidad y vanguardias 1957/1983. Buenos Aires: Fondo Nacional de las Artes, Vol. I.

Fernández, L. y Vázquez, M. (1999). Objetivo: corto. Guía práctica del cortometraje en España. Madrid: Nuer Ediciones.

Flores, S. (2013). "Cine y periferia: la representación de los espacios e individuos marginales en el cine argentino de los años sesenta". Contemporánea comunicação e cultura, 11, 3, 446-463.

Gramsci, A. (1981). Escritos políticos (1917-1933), Cuadernos de Pasado y Presente, México, Siglo XXI editores, 54.

Ickowicz, L. I. (2008). En tiempos Breves. Apuntes para la escritura de cortos y largometrajes. Buenos Aires, Ediciones Paidós SAICF.

Lusnich, A. L. (2007). El drama social-folclórico. El universo rural en el cine argentino. Buenos Aires: Biblos.

Massari, R., Peña, F. M. y Vallina, C. (2006). Escuela de Cine, Universidad Nacional de La Plata: creación, rescate y memoria. La Plata: UNLP.

Mastracchio, L. R. (Comp.) (2006). Instituto Cinefotográfico UNT. 60 años (19462006). San Miguel de Tucumán: Escuela de Cine, Video y Tv de la UNT.

Monterde, J. E. (1996). "La modernidad cinematográfica". En Historia General del Cine. Madrid: Ediciones Cátedra, IX, 15-45.

Monterde, J. E., Riambau, E. y Torreiro, C. (1987). "Procedencias y aprendizajes”. En Los “nuevos cines” europeos, 1955/1970. Barcelona: Lerna.

Moreschi, O. (2012). "Construir la memoria. El Departamento de Cine de la Escuela de Artes de la Universidad Nacional de Córdoba”. Toma Uno, 1, 207-222.

Pécora, P. (2008). "Algunas reflexiones sobre el cortometraje”. En Russo, R. (Comp.), Hacer Cine: Producción audiovisual en América Latina. Buenos Aires: Paidós, 377-387. 
Ramírez Llorens, F. (2013). "Un espacio interminable de intercambios culturales. Conversaciones con Oscar Moreschi sobre el cine en Córdoba en las décadas del 60 y 70". En Entrevistas de la Red de Historia de los Medios 02. Buenos Aires: ReHIMe, 7-73.

Rossi, J. J. (Comp.) (1987). El cine documental etnobiográfico de Jorge Prelorán. Buenos Aires: Ediciones Búsqueda.

Velleggia, S. (1986). Cine: Entre el espectáculo y la realidad. México: Claves Latinoamericanas. 
